\title{
Microbial Contamination and Pathogenecity Related with Quality of Drinking Water of Rural Areas of Dera Ghazi Khan
}

\author{
Ayaz Ahmad ${ }^{1 *}$ and Sahrish Khan ${ }^{2}$ \\ ${ }^{1}$ Assistant Professor of Biology Govt. Degree College Block.no.17 D.G.Khan, Pakistan \\ ${ }^{2}$ Department of Biotechnology, Quaid-e-Azam University, Pakistan
}

*Corresponding author: Ayaz Ahmad, Assistant Professor of Biology Govt. Degree College Block.no.17 DG Khan, Punjab, Pakistan.

\begin{abstract}
Water is very important solvent to perform the functions of human body and the quality of water is very important. The present study was carried out to check the quality of drinking water of rural areas on the basis of turbidity and microbial contamination of D.G.Khan. Rural areas are at very much-diversified locations; usually water in this area is salty. Safe drinking water availability is very common problem of residents. The purpose of our study was also to check that on what parameters water is highly rejected and not safe for drinking purpose with high health risk. Total of 150 samples were collected and brought to the laboratories for analysis from 5 different villages, Gud Pur, Lohar wala, Mamoory, Jamna Chandia and Basti Malanga. Water samples from 9 different locations from each Village. The sampling was done in a systematic randomized way started from each village in sterilized bottles and were brought to the laboratory for analysis. Though the water used for drinking purpose in the study area was obtained from the clean water supply systems including water supplies, hand pumps, and filtration plants. Despite of this the water people were drinking was found contaminated with Turbidity, Bacteria's and E.coli bacteria. The Turbidity value of all the water samples collected from all villages was less than 5 NTU except two samples that was above the limits of the standard given by World Health Organization. All the results were statistically analyzed by Anova. In This study it was proved that contaminated water is responsible for many microbial disorders like cholera, Ringworm, Trachoma, Hepatitis, Epilepsy, Mental retardation and High blood Pressure.
\end{abstract}

Keywords: Drinking water; Pollution; Microorganism; Microbial disorders; Rural area of DG Khan

\section{Introduction}

The major causes of water to induce diseases in humans are viruses, protozoa, helminths and bacteria. All the species of these organisms are not always disease causing instead some species of these organisms are very beneficial to humans. From these organisms diseases have been reported in well developed and progressed countries but their rate is quite high in the under developed countries rural and suburban areas. It is because these countries have limited resources and they have in sufficient managing techniques for water quality. The most important Microbial pollution sources found in the distribution network of water is due to cross-contamination with sewers and illegal connections. In Pakistan, many workers did bacteriological survey of drinking water [1]. Abundance of algae, during the summer season, there is taste and odor problems in drinking water, at the water treatment plant. Terrestrial-fresh-brackish- and seawater cyanobacteria of cosmopolitan occurrence produce Cyanobacterial toxins. These toxins present acute and chronic hazards to human and animal health [2,3]. Human health problems are associated with the ingestion and contact with cyanobacterial blooms and their toxins [4,5]. Massive proliferation cyanobacteria is caused by total nitrogen which results eutrophication are produced by dominant species of cyanobacteria which is a potent liver cancer promoter $[6,7]$, Water quality at the source and point of consumption among rural and peri-urban communities in northern Sudan. Both water 
sources and water stored for consumption had fecal bacteria counts grossly in excess of WHO stands, with higher counts at the end of the rainy season. The study had shown that poor quality water continues to be a major risk factor for public health in these communities $[8,9]$. When people use water directly for bathing, swimming or drinking they get diseased due to contamination in water. If pathogens are present in water, they either get into human body directly through drinking or they enter through contact with skin. Water should be clean in order to avoid from ingestion of protozoa, bacteria, viruses and helminthes. Broad range diseases can be faced due to water contaminated with these organisms but the gastrointestinal tract disturbance leading to diarrhea is more common $[10,11]$. Cholera is another disease which can be treated and cured. It is caused by bacterium vibrio cholera. If the disease it left untreated $50 \%$ of the deaths can occur with the sudden symptoms of vomiting, water diarrhea and nausea. Only $1 \%$ deaths occur if the treatment is sought. If bad sanitary conditions and leaky sewerage is present, then water contamination must cause serious health effects. Bad sanitation can induce harmful chemical substances into the clean water. Microbial contamination in such water can cause ringworm and trachoma. Ringworm is caused by a fungus. Trachoma is caused by a bacterium and it is an infection of the eyes $[12,13]$. Different types of pathogenecity are been associated with different microorganisms isolated from drinking water. Bacteria usually isolated from drinking water include all the members of the family Eneterobacteriaceae such as E. coli, Salmonella, Shigella, Proteus, Serratia, Enterobacter, and Citrobacter etc. staphylococcus, Pseudomonas, Enterococcus and Bacillus etc. These organisms may cause a wide range of infections and intoxication like abscesses, boils, styes, emphymia, antibiotic associated enteritis, meningitis, furunculosis, pyaemia, osteomylitis, suppuration of wound, and food poisoning, enteric infections, gastroenteritis, diarrheal diseases, dysentery, cystitis, pyelitis, pyelobephritis, wound infection, appendicitis, infections of the gall bladder, bacteremia, meningitis especially of the new born $[14,15]$.

\section{Material and Methodology}

The collected samples were analyzed from the soil and water testing laboratory of Government of Punjab in D.G.Khan.

\section{Sampling}

All the sampling and preservation procedures for water samples was be adopted according to standard methods as indicated and recommended for the examination of water [1] and an examination of water for pollution control by following the guidelines for drinking water quality evaluation (WHO, 1996).

Total of 150 samples were collected and brought to the laboratories for analysis from 5 different villages, Gud Pur, Lohar wala, Mamoory, jamna Chandia and Basti Malanga. Water samples from 9 different locations from each Village. The sampling was done in a systematic randomized way started from each village in sterilized bottles and were brought to the laboratory for analysis.

\section{Result}

Tables (1-8)

Table 1: Analysis of variance (ANOVA) for Turbidity of water samples collected from five different villages.

\begin{tabular}{|c|c|c|c|c|c|c|}
\hline \multirow[b]{2}{*}{ Source of Variance } & \multirow[b]{2}{*}{ DF } & \multicolumn{5}{|c|}{ Mean Sum of Squares (MS) } \\
\hline & & Gud Pur & Lohar wala & Mamoory & Jamna Chandia & Basti Malanga \\
\hline Location & 8 & $0.335^{* *}$ & $0.761^{* *}$ & $0.087^{* *}$ & $10.28^{* *}$ & $11.6^{* *}$ \\
\hline Error & 20 & 0.0003 & 0.028 & 0.0005 & 0.004 & 0.002 \\
\hline
\end{tabular}

$* *=$ Highly Significant $(p<0.05)$

Table 2: The Mean Turbidity values of Water samples collected from all villages.

\begin{tabular}{|c|c|c|c|c|c|}
\hline Area & Gud Pur & Lohar Wala & Mamoory & Jamna Chandia & Basti Malanga \\
\hline $\mathrm{A}_{1}$ & 0.67 & 0.53 & 0.51 & 0.53 & 0.53 \\
\hline $\mathrm{A}_{2}$ & 1.38 & 1.36 & 0.51 & 6.36 & 1.36 \\
\hline $\mathrm{A}_{3}$ & 1.09 & 0.35 & 0.36 & 0.53 & 0.47 \\
\hline $\mathrm{A}_{4}$ & 0.86 & 0.39 & 0.42 & 0.32 & 0.65 \\
\hline $\mathrm{A}_{5}$ & 0.79 & 0.78 & 0.53 & 0.58 & 0.02 \\
\hline $\mathrm{A}_{6}$ & 1.25 & 0.64 & 0.37 & 0.32 & 0.41 \\
\hline $\mathrm{A}_{7}$ & 1 & 0.44 & 0.28 & 0.56 & 0.55 \\
\hline $\mathrm{A}_{8}$ & 0.54 & 2.8 & 0.55 & 0.62 & 0.31 \\
\hline $\mathrm{A}_{9}$ & 0.46 & 0.5 & 0.01 & & 0.47 \\
\hline
\end{tabular}


Table 3: Analysis of variance (ANOVA) for TPC of water samples collected from all villages.

\begin{tabular}{|c|c|c|c|c|c|c|}
\hline \multirow{2}{*}{$\begin{array}{c}\text { Source of Vari- } \\
\text { ance }\end{array}$} & DF & Gud Pur & Lohar Wala & Mamoory & Jamna Chandia & Basti Malanga \\
\cline { 3 - 7 } & 8 & $6042^{* *}$ & $7617^{* *}$ & $8655^{* *}$ & $9507^{* *}$ & $1178^{* *}$ \\
\hline Location & 20 & 59 & 169 & 39.9 & 665 & 850 \\
\hline Error & & & & & \\
\hline
\end{tabular}

** $\quad=\quad$ Highly Significant $(p<0.05)$

Table 4: The Mean Turbidity values of Water samples collected from all villages.

\begin{tabular}{|c|c|c|c|c|c|}
\hline Area & Gud Pur & Lohar Wala & Mamoory & Jamna Chandia & Basti Malanga \\
\hline $\mathrm{A}_{1}$ & 106.7 & 103.67 & 109.77 & 87.67 & 115 \\
\hline $\mathrm{A}_{2}$ & 133 & 69.67 & 60.33 & 102.67 & 74 \\
\hline $\mathrm{A}_{3}$ & 76.67 & 86.67 & 87.67 & 756 & 90.67 \\
\hline $\mathrm{A}_{4}$ & 17.1 & 67 & 100.67 & 65.67 & 112 \\
\hline $\mathrm{A}_{5}$ & 133.67 & 106.34 & 109 & 108 & 106 \\
\hline $\mathrm{A}_{6}$ & 103 & 106.02 & 133.33 & 113 & 118.33 \\
\hline $\mathrm{A}_{7}$ & 99.67 & 84.67 & 82.33 & 82.67 & 141 \\
\hline $\mathrm{A}_{8}$ & 87 & 104.35 & 114 & 108.67 & 118.67 \\
\hline $\mathrm{A}_{9}$ & 79.33 & 95.33 & 80.67 & 86 & 85.33 \\
\hline
\end{tabular}

Table 5: Analysis of variance (ANOVA) for TPC of water samples collected from all villages.

\begin{tabular}{|c|c|c|c|c|c|c|}
\hline \multirow{2}{*}{$\begin{array}{c}\text { Source of Vari- } \\
\text { ance }\end{array}$} & \multirow{2}{*}{ DF } & Gud Pur & Lohar Wala & Mamoory & Jamna Chandia & Basti Malanga \\
\cline { 3 - 7 } & 8 & $6042^{* *}$ & $7617^{* *}$ & $8655^{* *}$ & $9507^{* *}$ & $1178^{* *}$ \\
\hline Location & 20 & 59 & 169 & 39.9 & 665 & 850 \\
\hline Error & & & \multicolumn{5}{|c|}{ Mean Sum of Squares (MS) } \\
\hline
\end{tabular}

** $\quad=\quad$ Highly Significant $(p<0.05)$

Table 6: The Mean Total Bacterial values of Water samples collected from all villages.

\begin{tabular}{|c|c|c|c|c|c|}
\hline Area & Gud Pur & Lohar Wala & Mamoory & Jamna Chandia & Basti Malanga \\
\hline $\mathrm{A}_{1}$ & 0 & 17 & 0 & 13.33 & 0.8 \\
\hline $\mathrm{A}_{2}$ & 23.49 & 116.67 & 9 & 0.33 & 11 \\
\hline $\mathrm{A}_{3}$ & 9.33 & 8.33 & 0.67 & 0 & 22.33 \\
\hline $\mathrm{A}_{4}$ & 0 & 142.67 & 13.63 & 0 \\
\hline $\mathrm{A}_{5}$ & 16 & 9.35 & 5 & 0 & 0 \\
\hline $\mathrm{A}_{6}$ & 7.33 & 11.67 & 0 & 13 & 3 \\
\hline $\mathrm{A}_{7}$ & 2.67 & 15.67 & 10 & 0 & 0 \\
\hline $\mathrm{A}_{8}$ & 12.33 & 14.43 & 0 & 0 & 17 \\
\hline $\mathrm{A}_{9}$ & 0.33 & 0 & 0 & 0 \\
\hline
\end{tabular}

Table 7: Analysis of variance (ANOVA) for TPC of water samples collected from all villages.

\begin{tabular}{|c|c|c|c|c|c|}
\hline \multirow{2}{*}{ Source of Variance } & \multirow{2}{*}{ DF } & \multicolumn{4}{|c|}{ Mean Sum of Squares (MS) } \\
\cline { 3 - 6 } & & Gud Pur & Mamoory & Jamna Chandia & Basti Malanga \\
\hline Location & 8 & $6042^{* *}$ & $8655^{* *}$ & $9507^{* *}$ & $1178^{* *}$ \\
\hline Error & 20 & 59 & 39.9 & 665 & 850 \\
\hline
\end{tabular}

** $\quad=\quad$ Highly Significant $(p<0.05)$ 
Table 8: The Mean E.coli values of Water samples collected from five different villages.

\begin{tabular}{|c|c|c|c|c|c|}
\hline Area & Gud Pur & Lohar Wala & Mamoory & Jamna Chandia & Basti Malanga \\
\hline $\mathrm{A}_{1}$ & 0.33 & 0 & 0 & 0 & 0 \\
\hline $\mathrm{A}_{2}$ & 2 & 1.67 & 0 & 0 & 0 \\
\hline $\mathrm{A}_{3}$ & 1 & 0 & 1.33 & 1.33 & 0 \\
\hline $\mathrm{A}_{4}$ & 0.33 & 1.33 & 0 & 0.33 & 0 \\
\hline $\mathrm{A}_{5}$ & 1.33 & 1.33 & 0 & 1 & 0 \\
\hline $\mathrm{A}_{6}$ & 2.33 & 1.67 & 1.33 & 0 \\
\hline $\mathrm{A}_{7}$ & 0 & 1.33 & 2.67 & 0 & 1.33 \\
\hline $\mathrm{A}_{8}$ & 1.33 & 0 & 1.33 & 1 & 2.33 \\
\hline $\mathrm{A}_{9}$ & 1 & 1 & & & 0.33 \\
\hline
\end{tabular}

\section{Discussion}

Mental retardation, learning disabilities mostly in children, and other behavioral problems might be caused by the contaminated water. Epilepsy has also been observed in two persons in mamoory village. Epilepsy and High blood pressure were noticed in average of $10.34 \%$, and $33.10 \%$ respectively. The possible cause of these diseases might be the consumption of water contaminated or there might be some other reasons for these diseases in humans [14]. In some areas Shortness of breath, vomit and nausea was observed. The Turbidity value of all the water samples collected from all villages was less than 5 NTU except two samples that was above the limits of the standard given by World Health Organization, which described that the Turbidity of drinking water should be (5 NTU) [15]. The TPC value of half of the water samples collected from all villages was above the limits of the standard given by World Health Organization which described that the TPC of drinking water should be $(<100 / 1 \mathrm{ml})$ and $(<100 / 1 \mathrm{ml})$, respectively. The results obtained from the samples showed that in almost all the samples bacterial population was found. Half of the samples were exceeding the standard values adjusted for the TPC. Some areas were prevailed by diarrheal and gastrointestinal diseases where the values of Total plate count colonies were above the limits and water was contaminated with bacterial populations. The statistical results for E.coli value of the samples collected from Gud Pur, Lohar Wala, Mamoory, Jamna Chandia and Basti Malanga revealed that the differences in E.coli value of the water samples collected from each village were highly significant. The results of this study were in good agreement to those presented by Funari \& Ottaviani [9] explaining the key factors of hygienic quality of water and their effects on community health. Microbial contamination more specifically E.coli might be the possible cause of Gastrointestinal illnesses, typhoid and diarrhea. Possible Potential causes for the microbial illnesses might be E.coli.

\section{Conclusion}

In This Study Different parameters confirmed that microbial contamination and turbidity of water is responsible for much human illness.

\section{Acknowledgement}

We thank Dr. Hyun Ho Shin at KIOST for providing algal cultures for testing. The study was funded by Chungnam National University.

\section{Conflict of Interest}

No conflict of interest.

\section{References}

1. APHA (1995) Standard Methods for the Examination of water and wastewater $18^{\text {th }}$ Edn. American Public Health Association, Washington DC, USA pp.4-25.

2. APHA (1998) Standard Methods for the Examination of Water and Wastewaters, $20^{\text {th }}$ Edn. American Public Health Association, Washington DC, USA pp. 5-30.

3. Bagchi S (2007) Arsenic threat reaching global dimensions. CMAJ 177 (11): 1344-45.

4. Braun CL, Smirnov SN (2003) Why is water blue? J Chemistry Education 70: 612 .

5. Campbell N, Williamson AB, Robin L, Heyden (2006) Food contaminants and wastes. J Bio Exploring Life 54:13.

6. Dean HT (1942) Epidemiological studies in the United States, In: Moulton FR Fluorine and dental health, Washington DC, American J Association for the Advancement of Sci 19: 34-35.

7. Edberg SC, Leclere H, Robertson J (1997) Natural protection of spring and well drinking water against surface microbial contamination. Indicators and monitoring parameters parasites J Criteria Revolu Micro 23: 179-206.

8. Fu BX (2008) Asian noodles: History, classification, raw materials, and processing. J britan on Food Resource 41(9): 888-902.

9. Funari E, Ottaviani M (1997) Hygienic and health aspects of drinking water. J Pathology 6: 13-15.

10. Greenhalgh A (2013) Water. BBC Health, 2001 Assessed on 01. 07 J Healthy living.

11. Ljubas D (2005) Solar photocatalysis-a possible step in drinking water treatment. J water Envi Pollution 30: 1699-1710.

12. Maria K (2003) The Water Framework Directive: A New Directive for a Changing Social, Political and Economic European Framework. J Europe Plans for water research 11 (3): 299-316.

13. Mohod CV, Dhote J (2013) Review of heavy metals in drinking water and their effect. Inter J Innovative Research in Sci Eng Tech 2: 2992-2996.

14. Mohsin M, Safdar S, Asghar F, Jamal F (2013) Assessment of Drinking Water Quality and its Impact on Residents Health in Bahawalpur City. Inter J Human Soc Sci 3(15).

15. Monarca S, Donato S, Zerbini F, Calderon RL, Craun GF (2006) Review of epidemiological studies on drinking water hardness and cardiovascular diseases. Euro J Card Disease Prevention 13(4): 495-506. 